\title{
EFFECT OF LUTEINIZING HORMONE ON PROGESTIN LEVELS IN RABBIT CORPORA LUTEA
}

\author{
HELEN E. KELLEY AND F. STORMSHAK \\ Animal Husbandry Research Division, U.S. Department of Agriculture, \\ Beltsville, Maryland 20705, U.S.A.
}

(Received 24th April 1969)

\begin{abstract}
Summary. Rabbits were injected intravenously with luteinizing hormone (LH) or saline solution on Day 9 of pseudopregnancy and killed $\frac{1}{2}, 24$ or $48 \mathrm{hr}$ later. Corpora lutea of LH-treated animals had decreased significantly in size and progesterone content at 24 and $48 \mathrm{hr}$ compared to corpora lutea of control rabbits. Luteal content and

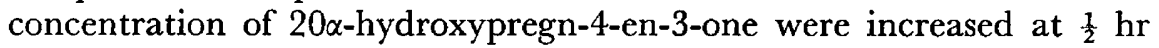
but decreased over the next $48 \mathrm{hr}$.
\end{abstract}

Morphological regression of mature corpora lutea (CL) results from the injection of luteinizing hormone $(\mathrm{LH})$ into pseudopregnant or pregnant rabbits (Foster, 1938; Spies, Coon \& Gier, 1966; Stormshak \& Casida, 1965). Luteinizing hormone stimulates synthesis of 20 $\alpha$-hydroxypregn-4-en-3-one in rabbit CL in vitro (Dorrington \& Kilpatrick, 1966). Therefore, injected LH might alter luteal steroidogenesis in vivo. The present experiment was conducted to study the effect of injected LH on luteal weight and progestin levels in pseudopregnant rabbits.

Thirty mature Dutch-Belted female rabbits were assigned randomly to six groups of five animals each in an experiment of $2 \times 3$ factorial design. All animals were made pseudopregnant by mating with vasectomized males (day of mating = Day 0 of pseudopregnancy). On Day 9 of pseudopregnancy, rabbits in each of three groups received a single intravenous injection of 50 $\mu \mathrm{g}$ of NIH-LH-s-9. This dose level was chosen because it consistently caused regression of mature CL of pseudopregnant rabbits in previous studies (Stormshak \& Casida, 1965). Rabbits in the remaining three groups were injected on Day 9 with saline. Autopsies were carried out on treated and control rabbits $\frac{1}{2}, 24$ or $48 \mathrm{hr}$ after injection and mature CL were dissected from the ovary, weighed and stored in $95 \%$ ethanol.

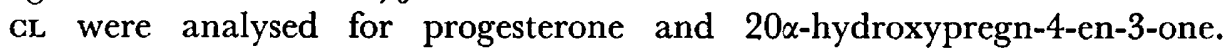
Labelled steroid (progesterone-4- ${ }^{14} \mathrm{C}, 20 \alpha$-hydroxypregn-4-en-3-one-1,2- ${ }^{3} \mathrm{H}$; New England Nuclear Corp.) was added to the samples to correct for losses incurred during extraction and purification. Luteal tissue was homogenized in $95 \%$ ethanol and filtered. The filtrate was dried under vacuum and further purified by column and paper chromatography as described previously

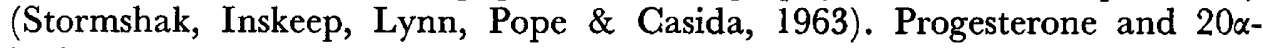
hydroxypregn-4-en-3-one were separated by paper chromatography with the 


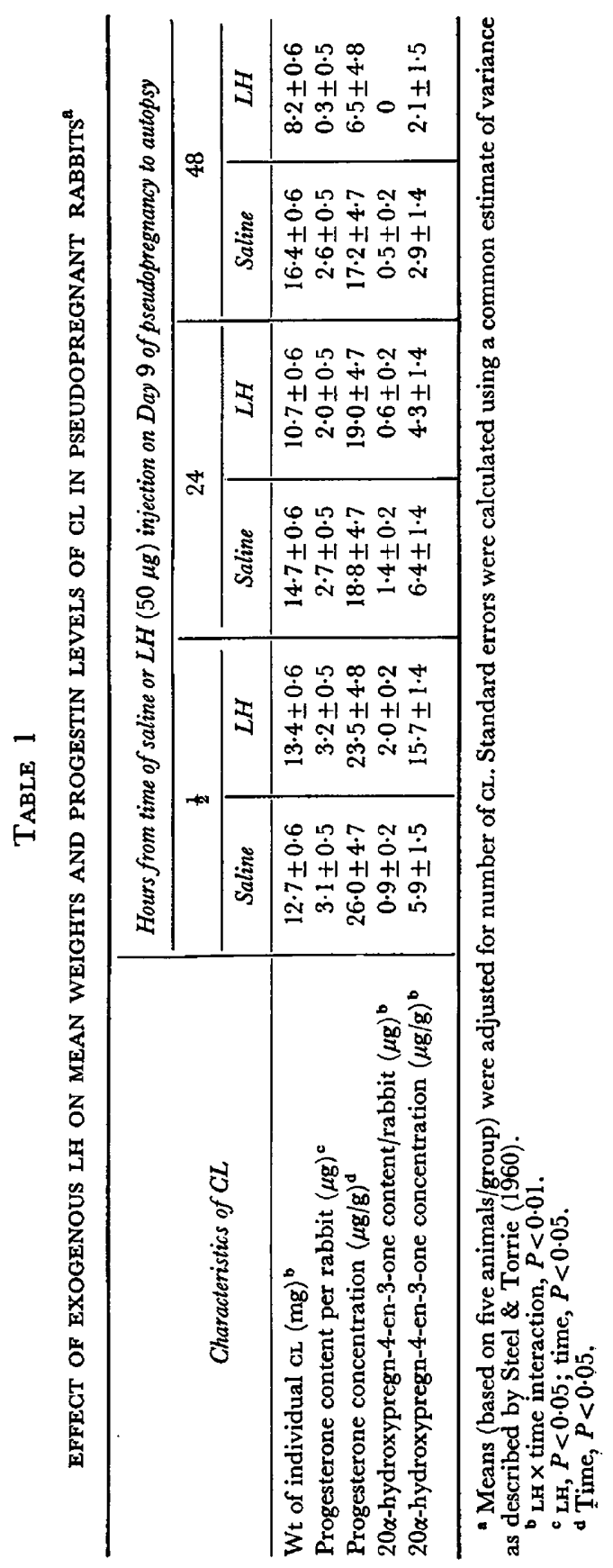


following modification: paper chromatograms were equilibrated overnight instead of for $1 \mathrm{hr}$. Quantitation of steroid was made by measuring sample absorption at $230 \mathrm{~m} \mu$ and $240 \mathrm{~m} \mu$ in a DU spectrophotometer (Stormshak et al., 1963). The recovery of progesterone and $20 \alpha$-hydroxypregn-4-en-3-one averaged $66 \cdot 6 \pm 6 \cdot 2$ and $66 \cdot 3 \pm 6 \cdot 1 \%$, respectively.

Luteal weights and luteal progestin content and concentration were adjusted by covariance for number of CL. Standard errors were calculated using a common estimate of variance as described by Steel \& Torrie (1960).

As shown in Table 1, CL of control animals continued to grow during the 48-hr period studied, but glands in LH-treated rabbits had begun to regress in size by $24 \mathrm{hr}$ after injection and had regressed even further by $48 \mathrm{hr}$ ( $\mathrm{LH} \times$ time interaction, $P<0.01$ ). In treated animals, luteal progestin (progesterone and $20 \alpha$-hydroxypregn-4-en-3-one) content and concentration decreased over time. The reduction in progesterone content of CL was greater in treated animals than in controls $(P<0.05)$, the effect of treatment being particularly apparent $48 \mathrm{hr}$ after injection. Luteal progesterone concentration decreased with time but the effect of treatment was not significant statistically. Luteal $20 \alpha$-hydroxypregn-4-en-3-one content and concentration increased initially $\left(\frac{1}{2} \mathrm{hr}\right)$ in treated animals but decreased as CL regressed ( $\mathrm{LH} \times$ time interaction, $P<0 \cdot 01$ ).

These data indicate that $\mathbf{L H}$ injected into pseudopregnant rabbits causes luteal regression with reduction in the concentration of luteal progesterone and

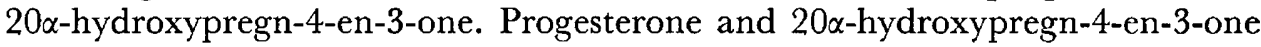
are the major secretory steroids synthesized by the CL of the rabbit (Dorrington \& Kilpatrick, 1966; Gorski, Padnos \& Nelson, 1965; Telegdy \& Savard, 1966). In addition, androstenedione (androst-4-ene-3,17-dione), 20 $\beta$-hydroxypregn4-en-3-one, 17 $\alpha$-hydroxypregn-4-ene-3,17-dione, testosterone and dehydroepiandrosterone ( $3 \beta$-hydroxyandrost-5-en-17-one) are also synthesized in trace amounts by rabbit luteal tissue (Telegdy \& Savard, 1966). Of the latter steroids, androstenedione was present in greatest quantity. With the exception of progesterone and 20 $\alpha$-hydroxypregn-4-en-3-one, there were no other visible ultra-violet light absorbing areas on the developed chromatograms in the present study.

A part of the detrimental action of exogenous LH on the CL of the rabbit might be related to the ability of this gonadotrophin, acting either directly or indirectly, to alter the synthesis or metabolism of 20x-hydroxypregn-4-en-3-one. The initial increase in luteal 20x-hydroxypregn-4-en-3-one content and concentration in LH-treated animals of this study is similar to the reported effect of LH on rabbit ovarian interstitial progestin secretion (Hilliard, Archibald \& Sawyer, 1963). It has been suggested that ovarian follicular secretion of oestrogen is necessary for luteal maintenance in the rabbit and that ovulation induced by the injection of $\mathrm{LH}$ interrupts oestrogen secretion, resulting in regression of CL (Keyes \& Nalbandov, 1968).

The authors gratefully acknowledge $\mathrm{Dr} \mathrm{H}$. W. Hawk for suggestions throughout the study and the assistance of R. L. Wilson, ARS Biometrical Services, in the statistical analysis of the data. They wish to thank the Endocrinology Study 
Section, National Institutes of Health and Dr R. G. Zimbelman, The Upjohn Company, for gifts of NIH-LH-s-9 and authentic 20x-hydroxypregn-4-en-3-one, respectively.

\section{REFERENCES}

Dorrington, J. H. \& Kilpatrick, R. (1966) Effects of pituitary hormones on progestational hormone production by the rabbit ovary in vivo and in vitro. $\mathcal{F}$. Endocr. 35, 53.

Foster, M. A. (1938) The differential action of pituitary gonadotropic hormones upon the secretory capacity of the Graafian follicle and corpus luteum. Am. F. Physiol. 121, 633.

Gorski, J., Padnos, D. \& Nelson, N. J. (1965) In vitro effects of luteinizing hormone on rabbit ovaries. Life Sci. 4, 713.

Hilliard, J., Archibald, D. \& Sawyer, C. H. (1963) Gonadotropic activation of preovulatory synthesis and release of progestin in the rabbit. Endocrinology, 72, 59.

Keyes, P. L. \& Nalbandov, A. V. (1968) A mechanism for LH-induced regression of corpora lutea in rabbits. F. Reprod. Fert. 17, 183.

SPIEs, H. G., Coon, L. L. \& Guer, H. T. (1966) Luteolytic effect of LH and HCG on the corpora lutea of pseudopregnant rabbits. Endocrinology, 78, 67.

Steel, R. G. D. \& Torrie, J. H. (1960) Principles and procedures of statistics, 316. McGraw-Hill, New York.

Stormshax, F. \& Casida, L. E. (1965) Effects of LH and ovarian hormones on corpora lutea of pseudopregnant rabbits. Endocrinology, 77, 337.

Stormshak, F., Inskeep, E. K., Lynn, J. E., Pope, A. L. \& Casida, L. E. (1963) Progesterone levels in corpora lutea and ovarian effluent blood of the ewe. J. Anim. Sci. 22, 1021.

Telegdy, G. \& SAvARd, K. (1966) Steroid formation in vitro in rabbit ovary. Steroids, 8, 685. 